\title{
Consumer Federation of America
}

\author{
THE FINANCIAL CONDITION OF WOMEN ON THEIR OWN
}

Stephen Brobeck and Catherine Montalto

June 2008

$\underline{\text { Introduction }}$

There has been little research on female savings habits and adequacy. In part, this is because of the diverse household situations of women, ranging from women who live by themselves to those who are married with children. These diverse situations are paralleled by significant differences in financial condition, with married women tending to be more affluent than those who head their own households.

These "women on their own" deserve special attention because they lack the financial advantages of a second income, which typically would be higher than their own because men tend to earn more than women. The purpose of this report is to use the Federal Reserve Board's latest Survey of Consumer Finances, the most accessible and reliable source of information about family finances, to analyze the savings habits and adequacy of "households with a female householder who is not married or living with a partner." In 2004, there were 31 million such households representing more than one-quarter $(26 \%)$ of all households.

\section{Demographic Characteristics}

The 31 million women who head these households can be divided into three different groups -- those who never married (9 million), those who are divorced or separated (12 million), and those who are widowed (9 million). (All these figures are rounded off to the nearest million.) As Table 1 indicates, the never married tend to be young, with over half $(51 \%)$ being under 35 years of age. The divorced or separated tend to be middle-aged, with over half (56\%) being between 35 and 55 years of age. And the widowed tend to be old, with well over twothirds $(71 \%)$ being at least 65 years of age.

Women on their own are disproportionately African-American, especially those who never married. Thirty-seven percent of women on their own who never married, and 21 percent who are divorced or separated, are African-American. Yet, only 13 percent of all households are African-American. 
Overall, women on their own are less likely to have dependent children than are other households. Fifty-four percent of all households, but 61 percent of those headed by women on their own, have no children. This is largely because 79 percent of widowed women on their own have no children. Yet, slightly more than half of divorced or separated women on their own (51\%), and even 40 percent of those never married, have at least one dependent child in the household.

Women on their own have less education than all household heads: For instance, more do not have a high school degree (19\% vs. $14 \%)$, and fewer have a college degree ( $28 \%$ vs. $37 \%)$. Yet, this overall difference masks significant differences among the three groups of women, with 40 percent of the never married, 28 percent of the divorced or separated, and only 18 percent of the widowed having college degrees. In all probability these educational differences mainly reflect age differences: Young women are far more likely than older women to have a bachelor's degree.

Age also helps explain differences in labor-force participation between women on their own and all household heads. The proportions of divorced or separated women and never married women who work full-time $(57 \%$ and $62 \%$ ) differ little from the proportion of all household heads who work full-time (63\%). But because only 17 percent of widows work fulltime, the proportion of all women on their own who are full-time workers is only 46 percent. Certainly the fact that a large majority of widows are at least 65 years of age mainly explains these relatively low percentages.

Women on their own are much less likely to own their homes than are all household heads $(54 \%$ vs. $69 \%)$. But this difference mainly reflects the fact that only 33 percent of never married women are home owners. The proportion of widowed women who are home owners is actually higher than that of all other household heads.

\section{Financial Characteristics}

The income of women on their own is significantly lower than that of all households -$\$ 30,896$ vs. $\$ 70,628$ for average incomes, and $\$ 22,592$ vs. $\$ 43,130$ for median incomes. Somewhat surprisingly, as Table 1 indicates, the incomes of the three women on their own groups did not differ greatly: For instance, average incomes were $\$ 30,916$ for the never married, $\$ 32,049$ for the divorced or separated, and $\$ 29,386$ for the widowed.

However, there were significant differences in wealth among these three groups (Table 2 ). The median net worth of widows, at $\$ 100,800$, was actually higher than that of all households, at $\$ 93,001$. But the net wealth of divorced or separated women was much lower, at $\$ 30,400$, while that of never married women was only $\$ 6,210$. In fact, one-quarter of these never married had zero or negative net worth.

The Consumer Federation of America is particularly concerned about the ability of households to pay for unexpected expenditures, such as car repairs, using their own liquid 
financial assets. The proportion of women on their own with a savings or money market deposit account was somewhat lower than that for all households ( $48 \%$ vs. $58 \%$ ). And in all three groups of women on their own, less than half had savings accounts. Equally significant was the fact that never married and divorced or separated women with these savings typically had much less than all households -- $\$ 1,100$ and $\$ 1,600$ respectively versus $\$ 5,000$. For these two female groups, liquid savings was less than the savings they thought they needed for emergencies and other unexpected events -- $\$ 2,000$ for the never married and $\$ 2,500$ for the divorced or separated.

\section{$\underline{\text { Savings Habits }}$}

Most women on their own have saved much less than other households. One reason appears to be differences in savings habits: As Table 3 reveals, women on their own are less likely to save regularly and at all. Thirty-three percent of women on their own, but forty-one percent of all households, say they "save regularly. And 33 percent of women on their own say they "don't save," while this is true for only 24 percent of all households. The fact that widows

are much less likely to save or save regularly accounts for some of this difference but not all of it.

Women on their own are also less likely to have long planning horizons. Forty-two percent, but only 33 percent of all households, identify this horizon as a year or less, while only 29 percent of the women, but 39 percent of all households, say this horizon is at least five years.

Certainly the savings habits and realities for women on their own reinforce each other. Since their incomes are lower, they probably find it more difficult to save and, thus, save less than other households for emergencies and other savings goals. With less adequate liquid savings for unexpected expenditures, they are more likely to have shorter financial planning horizons.

\section{Conclusion}

Women on their own have significantly lower savings and wealth than do other households. The 21 million never married, divorced, or separated women are at a particular disadvantage financially because they hold far less wealth than do widows and all other households. An important reason for this wealth gap is significant differences in income among adults under the age of 65. Another reason is differences in home ownership: The never married, divorced, or separated are far less likely than widows and other households to own their own home. Other research suggests that one's home represents by far the most important source of wealth for low- to middle-income households.

Are women on their own doomed to be low savers and wealth-builders? Not at all, for the savings habits of these women vary considerably. For example 38 percent of the never married say they save regularly yet another 34 percent say they do not save. This large difference is also true for divorced or separated women. 
We do not have data that allow us to analyze these differences with any precision. But we do know, from other research, that a large majority of all women on their own can save regularly and that this saving is made easier by using automatic savings mechanisms such as payroll contributions to 401(k) and other savings accounts and by asking one's bank or credit union to automatically transfer funds, each month or pay period, from checking to savings. 
Table 1. Characteristics of All Households and Households with a Female Householder Who Is Not Married or Living With A Partner, 2004 Survey of Consumer Finances (column percents)

\begin{tabular}{|c|c|c|c|c|c|}
\hline \multirow[b]{2}{*}{ Characteristic } & \multirow{2}{*}{$\begin{array}{c}\text { All } \\
\text { Households }\end{array}$} & \multicolumn{4}{|c|}{$\begin{array}{l}\text { Households with a Female Householder Who Is } \\
\text { Not Married or Living With A Partner }\end{array}$} \\
\hline & & Total & $\begin{array}{l}\text { Divorced/ } \\
\text { separated }\end{array}$ & Widowed & $\begin{array}{c}\text { Never } \\
\text { Married }\end{array}$ \\
\hline \multicolumn{6}{|l|}{ Age of respondent } \\
\hline Less than 35 years & 22.19 & 20.13 & 11.71 & 0.67 & 51.38 \\
\hline 35 to 44 years & 20.62 & 17.83 & 25.75 & 1.74 & 23.85 \\
\hline 45 to 54 years & 20.77 & 17.83 & 30.43 & 5.96 & 13.26 \\
\hline 55 to 64 years & 15.24 & 15.24 & 16.19 & 20.99 & 8.06 \\
\hline 65 years and over & 21.19 & 28.97 & 15.92 & 70.63 & 3.46 \\
\hline \multicolumn{6}{|l|}{ Education of respondent } \\
\hline Less than high school & 14.43 & 18.94 & 14.51 & 32.11 & 11.28 \\
\hline High school graduate & 30.60 & 30.22 & 31.48 & 32.30 & 26.39 \\
\hline Some college & 18.37 & 22.63 & 26.75 & 17.53 & 22.39 \\
\hline Bachelor's degree & 36.61 & 28.21 & 27.75 & 18.05 & 39.94 \\
\hline \multicolumn{6}{|l|}{ Race/ethnicity of respondent } \\
\hline White nonhispanic & 71.82 & 65.32 & 64.37 & 79.77 & 51.71 \\
\hline Black nonhispanic & 13.41 & 24.00 & 20.84 & 15.68 & 36.78 \\
\hline Hispanic & 11.17 & 8.44 & 11.35 & 3.17 & 9.98 \\
\hline Nonhispanic, other races & 3.61 & 2.24 & 3.45 & 1.37 & 1.53 \\
\hline \multicolumn{6}{|l|}{ Marital status of respondent } \\
\hline Married & 57.97 & -- & -- & -- & -- \\
\hline Divorced/separated & 16.82 & 39.63 & 100.0 & -- & -- \\
\hline Widowed & 10.44 & 30.63 & -- & 100.0 & -- \\
\hline Never Married & 14.78 & 29.74 & -- & -- & 100.0 \\
\hline \multicolumn{6}{|l|}{ Total household income } \\
\hline First quintile & 20.21 & 42.49 & 36.86 & 47.80 & 44.53 \\
\hline Second quintile & 20.12 & 25.86 & 28.10 & 27.24 & 21.47 \\
\hline Third quintile & 19.79 & 20.10 & 21.65 & 15.88 & 22.37 \\
\hline Fourth quintile & 19.74 & 8.27 & 9.18 & 6.76 & 8.61 \\
\hline Fifth quintile & 20.15 & 3.28 & 4.21 & 2.32 & 3.03 \\
\hline \multicolumn{6}{|l|}{ Housing tenure } \\
\hline Home Owner & 69.05 & 54.44 & 55.97 & 73.41 & 32.87 \\
\hline Renter & 30.75 & 45.56 & 44.03 & 26.59 & 67.13 \\
\hline \multicolumn{6}{|l|}{ Labor market behavior of respondent } \\
\hline Employed full-time & 62.83 & 46.10 & 56.88 & 16.74 & 61.98 \\
\hline Employed part-time & 9.06 & 12.92 & 12.07 & 8.48 & 18.61 \\
\hline Not in the labor force & 28.10 & 40.98 & 31.05 & 74.78 & 19.42 \\
\hline \multicolumn{6}{|l|}{ Family size } \\
\hline One person & 30.65 & 64.90 & 52.64 & 85.51 & 60.00 \\
\hline Two persons & 33.39 & 17.56 & 21.74 & 9.18 & 20.61 \\
\hline Three persons & 14.82 & 10.66 & 17.34 & 2.14 & 10.54 \\
\hline Four or more persons & 21.14 & 6.89 & 8.29 & 3.17 & 8.85 \\
\hline \multicolumn{6}{|l|}{ Number of dependent children in the household } \\
\hline None & 54.45 & 61.64 & 49.26 & 79.39 & 59.84 \\
\hline One child & 19.48 & 19.50 & 23.55 & 12.84 & 20.96 \\
\hline Two children & 15.46 & 11.56 & 19.19 & 2.68 & 10.54 \\
\hline Three or more children & 10.62 & 7.30 & 8.00 & 5.09 & 8.66 \\
\hline Household receives welfare assistance ${ }^{2}$ & 7.70 & 16.95 & 18.62 & 11.15 & 20.71 \\
\hline Household receives Social Security benefits ${ }^{3}$ & 31.19 & 40.78 & 28.46 & 86.68 & 9.93 \\
\hline Mean & 49.56 & 52.82 & 49.95 & 72.21 & 36.67 \\
\hline & 48 & 52 & 49 & 75 & 34 \\
\hline
\end{tabular}




\begin{tabular}{|c|c|c|c|c|c|c|}
\hline \multirow{2}{*}{\multicolumn{2}{|c|}{ Characteristic }} & \multirow{2}{*}{$\begin{array}{c}\text { All } \\
\text { Households }\end{array}$} & \multicolumn{4}{|c|}{$\begin{array}{l}\text { Households with a Female Householder Who Is } \\
\text { Not Married or Living With A Partner }\end{array}$} \\
\hline & & & Total & $\begin{array}{l}\text { Divorced/ } \\
\text { separated }\end{array}$ & Widowed & $\begin{array}{c}\text { Never } \\
\text { Married }\end{array}$ \\
\hline \multicolumn{7}{|l|}{ Median } \\
\hline Family size & Mean & 2.26 & 1.60 & 1.81 & 1.23 & 1.68 \\
\hline Median & & 2 & 1 & 1 & 1 & 1 \\
\hline Number of dependent children & Mean & 0.88 & 0.70 & 0.92 & 0.38 & 0.72 \\
\hline Median & & 0 & 0 & 1 & 0 & 0 \\
\hline Total annual household income & Mean & $\$ 70,628$ & $\$ 30,896$ & $\$ 32,049$ & $\$ 29,386$ & $\$ 30,916$ \\
\hline Median & & $\$ 43,130$ & $\$ 22,592$ & $\$ 25,673$ & $\$ 19,511$ & $\$ 23,619$ \\
\hline
\end{tabular}

SOURCE: 2004 Survey of Consumer Finances (SCF04) represents 112.1 million U.S. households. All statistics calculated using the SCF final nonresponsive-adjusted sampling weights (X42001)

${ }^{1}$ Subsample of households with a female householder who is not married or living with a partner represents 30.6 million households:

12.1 million households with a divorced or separated female householder

9.4 million households with a widowed female householder

9.1 million households with a never married female householder

${ }^{2}$ Household received ADC, AFDC, food stamps, or other forms of welfare or assistance such as SSI

${ }^{3}$ Household received income from Social Security or other pensions, annuities, or other disability or retirement programs 
Table 2. Net Worth, Financial Assets and Savings Accounts for All Households and for Households with a Female Householder Who Is Not Married or Living with a Partner, 2004 Survey of Consumer Finances (column percents)

\begin{tabular}{|c|c|c|c|c|c|}
\hline \multirow[b]{2}{*}{ Variable } & \multirow{2}{*}{$\begin{array}{c}\text { All } \\
\text { Households }\end{array}$} & \multicolumn{4}{|c|}{$\begin{array}{l}\text { Households with a Female Householder Who Is } \\
\text { Not Married or Living With A Partner }\end{array}$} \\
\hline & & Total & $\begin{array}{l}\text { Divorced/ } \\
\text { separated }\end{array}$ & Widowed & $\begin{array}{c}\text { Never } \\
\text { Married }\end{array}$ \\
\hline \multicolumn{6}{|l|}{ Net worth } \\
\hline Median net worth (including zeros and negative values) & $\$ 93,001$ & $\$ 32,850$ & $\$ 30,400$ & $\$ 100,800$ & $\$ 6,210$ \\
\hline Percent of households with positive net worth & 91.10 & 84.40 & 83.79 & 94.73 & 74.58 \\
\hline Percent of households with net worth equal to zero & 1.76 & 3.60 & 3.69 & 1.49 & 5.64 \\
\hline Percent of households with negative net worth & 7.14 & 12.00 & 12.52 & 3.79 & 19.78 \\
\hline \multicolumn{6}{|l|}{ Net financial assets } \\
\hline Median net financial assets (including zero values) & $\$ 18,300$ & $\$ 4,000$ & $\$ 3,240$ & $\$ 10,100$ & $\$ 2,100$ \\
\hline Percent of households with positive net financial assets & 93.81 & 90.55 & 92.62 & 92.13 & 86.17 \\
\hline Percent of households with net financial assets equal to zero & 6.19 & 9.45 & 7.38 & 7.87 & 13.83 \\
\hline \multicolumn{6}{|l|}{ Savings accounts or MMDA } \\
\hline Median value of accounts for those with savings or MMDA & $\$ 5,000$ & $\$ 2,200$ & $\$ 1,600$ & $\$ 5,000$ & $\$ 1,100$ \\
\hline Percentage of families with savings accounts or MMDA & 57.65 & 47.84 & 49.89 & 46.11 & 46.89 \\
\hline \multicolumn{6}{|l|}{ Funds for emergencies } \\
\hline $\begin{array}{l}\text { Median level of savings perceived needed for emergencies and } \\
\text { other unexpected events }\end{array}$ & $\$ 5,000$ & $\$ 2,400$ & $\$ 2,500$ & $\$ 4,000$ & $\$ 2,000$ \\
\hline $\begin{array}{l}\text { Percent who could get emergency financial assistance of } \\
\$ 3,000 \text { or more from any friends or relatives who do not live } \\
\text { with the respondent }\end{array}$ & 65.79 & 54.79 & 52.74 & 59.17 & 53.03 \\
\hline
\end{tabular}


Table 3. Opinion and Expectation Variables of All Households and Households with a Female Householder Who Is Not Married or Living With A Partner, 2004 Survey of Consumer Finances (column percents)

\begin{tabular}{|c|c|c|c|c|c|}
\hline \multirow[b]{2}{*}{ Variable } & \multirow{2}{*}{$\begin{array}{c}\text { All } \\
\text { Households }\end{array}$} & \multicolumn{4}{|c|}{$\begin{array}{l}\text { Households with a Female Householder Who } \\
\text { Is Not Married or Living With A Partner }\end{array}$} \\
\hline & & Total & $\begin{array}{r}\text { Divorced/ } \\
\text { separated }\end{array}$ & Widowed & $\begin{array}{c}\text { Never } \\
\text { Married }\end{array}$ \\
\hline \multicolumn{6}{|l|}{ Planning horizon for saving and spending } \\
\hline Next few months & 19.20 & 26.10 & 28.61 & 25.17 & 23.73 \\
\hline Next year & 14.00 & 15.58 & 12.59 & 17.68 & 17.39 \\
\hline Next few years & 27.77 & 29.76 & 26.81 & 34.52 & 28.78 \\
\hline Next $5-10$ years & 25.72 & 19.18 & 21.23 & 17.16 & 18.54 \\
\hline Longer than 10 years & 13.32 & 9.38 & 10.77 & 5.47 & 11.56 \\
\hline \multicolumn{6}{|l|}{ Saving habits } \\
\hline Don't save - usually spend more than income & 7.04 & 10.38 & 11.52 & 8.97 & 10.30 \\
\hline Don't save - usually spend income & 16.48 & 22.37 & 22.24 & 22.49 & 22.43 \\
\hline Save whatever is left & 30.42 & 31.59 & 30.42 & 37.95 & 26.61 \\
\hline Save income of one earner & 2.30 & 0.67 & 0.19 & 0.67 & 1.30 \\
\hline Save transitory income; spend regular income & 4.85 & 3.96 & 3.59 & 5.03 & 3.37 \\
\hline Save regularly & 40.76 & 32.77 & 33.63 & 26.64 & 37.93 \\
\hline \multicolumn{6}{|l|}{ Relationship between spending and income } \\
\hline Spending greater than income & 15.41 & 20.92 & 21.53 & 19.68 & 21.39 \\
\hline Spending equal to income & 28.50 & 38.05 & 38.47 & 39.43 & 36.08 \\
\hline Spending less than income & 56.09 & 41.02 & 40.00 & 40.90 & 42.53 \\
\hline
\end{tabular}

